\title{
Comparison between the working environment of nurse managers and nursing assistants in the hospital context
}

\author{
Comparação entre ambiente de trabalho de enfermeiros gerentes e assistenciais no contexto \\ hospitalar \\ Comparación entre ambiente laboral de enfermeros gerentes y asistenciales en el marco \\ hospitalario
}

José Luís Guedes dos Santos ${ }^{1}$, Alacoque Lorenzini Erdmann¹, Caroline Cechinel Peiter², Murilo Pedroso Alves², Suzinara Beatriz Soares de Lima', Vânia Marli Schubert Backes ${ }^{1}$

How to cite this article:

Santos JLG, Erdmann AL, Peiter CC, Alves MP, Lima SBS, Backes VMS. Comparison between the working environment of nurse managers and nursing assistants in the hospital context. Rev Esc Enferm USP. 2017;51:e03300. DOI: http://dx.doi.org/10.1590/S1980-220X2017017103300

${ }^{1}$ Universidade Federal de Santa Catarina, Centro de Ciências da Saúde, Departamento de Enfermagem, Florianópolis, SC, Brazil.

${ }^{2}$ Universidade Federal de Santa Catarina, Programa de Pós-Graduação em

Enfermagem, Florianópolis, SC, Brazil.

\begin{abstract}
Objective: Comparing the working environment of nurse managers and nursing assistants in the hospital context. Method: A mixed methods research with concomitant triangulation of data developed in a university hospital in the South of Brazil. Participants in the quantitative study were 94 nursing assistants and 12 nurse managers. The data were collected using the Brazilian Nursing Work Index - Revised (B-NWI-R) and analyzed through descriptive and inferential statistics. Eight (8) nurse managers and 18 nursing assistants were interviewed for the qualitative study. The data were analyzed through thematic analysis. Results: The total B-NWI-R mean score for nurse managers was $2.15 \pm 0.39$, and for nursing assistants it was $2.22 \pm 0.39$. No statistical significance was identified in the comparison between the groups $(p=0.508)$. The qualitative results show the existence of collaborative relationships between nurse managers and nursing assistants. Conclusion: The working environment was similarly evaluated by nurse managers and nursing assistants in the hospital context.
\end{abstract}

\section{DESCRIPTORS}

Nursing; Working Environment; Nursing, Supervisory; Nursing Administration Research; Hospitals, Public. 


\section{INTRODUCTION}

The focus of nursing work is managing care and nursing services, which mainly involves activities of managing people and materials to achieve organizational objectives. Care management is an activity inherent to professional nursing practice. On the other hand, the management of nursing services is a responsibility of nurse managers or heads of the unit. These two spheres of nursing action articulate in the search for the excellence in care provided to the patient ${ }^{(1-2)}$.

Contemporary organizations seek nurse managers with skills and competencies to develop strategies for solving problems in the context of health and nursing work. It is also essential that the manager has the ability to coordinate the nursing team, seeking to recognize and meet their needs to ensure favorable working conditions that promote job satisfaction. Thus, they are expected to have knowledge on the management process in health and nursing, leadership ability and capacity to handle the responsibilities and duties of the position ${ }^{(1,3)}$.

Managerial activity often becomes discouraging in facing the demands, the organizational obstacles and the lack of support from the superior hierarchical levels of management in health institutions. This can make a manager's daily routine challenging and stressful, which discourages many professionals from taking up these positions. Moreover, nurses in exclusive leadership positions experience polarization between management and care, since in addition to the well-known managerial assignments, there is no consensus on the ideal level of involvement in nursing assistant activities ${ }^{(1,3)}$.

In this sense, it is important to point out that physical and organizational conditions of the nurse's working environment interfere in adequately performing their professional practice. Factors such as size of the institution or health service, management model, professional hierarchies, organizational culture, infrastructure and human and financial resources for implementing care can enhance or limit the nursing practice ${ }^{(4)}$. Thus, working environments that present these strengthened aspects bring greater professional satisfaction to nurses, influencing the quality of nursing care within the hospital environment ${ }^{(5)}$.

Despite the importance of the working environment characteristics for professional nursing practice, the scientific production on this topic is still scarce in Brazil. The existing studies come from the Southeast region and were carried out in the context of Intensive Care Units ${ }^{(6-}$ 9). In this sense, we point out the inexistence of previous research comparing the working environment of nurse managers and nursing assistants in the hospital context. Thus, this study proposed the following research question: What are the differences between the working environment of nurse managers and nursing assistants in the hospital context?

The objective of the research was to compare the working environment of nurse managers and nursing assistants within the hospital context.

\section{METHOD}

\section{StUdY DESIGN}

The present study is a mixed methods research with concomitant data triangulation (QUAN + QUAL). In this type of study, the quantitative and qualitative data are concomitantly collected and then compared for the purpose of identifying convergences, differences and combinations ${ }^{(10)}$.

\section{StUdy SCENARIO}

The study scenario was a public university hospital in the Southern Region of Brazil, with 268 beds that exclusively serves patients from the Brazilian Unified Health System (SUS - Sistema Único de Saúde). The institution has 17 nursing services organized into four Assistance Departments: Emergency and Ambulatory, Medical Nursing, Surgical Nursing, and Woman, Child and Adolescent Health. Each service has a nurse manager who is responsible for the management and the care of the unit, acting in both administration and direct care when necessary.

\section{DATA COLLECTION}

Quantitative and qualitative data were simultaneously collected between November 2012 and November 2013.

No sample calculation was used for quantitative data collection. The eligible population was composed of 162 full-time nurses working in the hospital's assistance departments at the time of data collection. Work experience time equal to or greater than 3 months in the current workplace was considered as inclusion criteria. Nurses who exclusively exercised managerial activities and/or those who were absent from the institution due to holidays and/or on leave were excluded from the study. Thus, a total of 132 suitable nurses were contacted and invited to participate in the study. Of this total, 106 (80.3\%) agreed to participate, of which 94 (88.7\%) were nursing assistants and $12(11.3 \%)$ were nurse managers.

Data collection instruments were a socio-demographic and professional characterization form, as well as the Brazilian Nursing Work Index - Revised instrument (B-NWI-R). The B-NWI-R was translated, adapted and validated for use in Brazil and it has the objective of measuring factors that interfere in the working environment of nurses. The instrument is composed of 15 items distributed into four subscales: control over the environment (seven items), autonomy (five items), relationships between physicians and nurses (three items) and organizational support (ten items originated from the first three subscales) ${ }^{(6,11)}$.

In the B-NWI-R, the participant is asked to answer whether or not they agree with the statement "this factor is present in my daily work", using a four-point Likert scale: I totally agree (one point), I partially agree (two points), I partially disagree (three points) and I totally disagree (four points). Thus, lower scores indicate the presence of favorable attributes, so that scores below and above 2.5 respectively correspond to favorable and unfavorable environments in their professional practice ${ }^{(8)}$.

Qualitative data were collected using semi-structured interviews with 18 nursing assistants and 8 nurse managers. 
The interviews were performed individually at the participants' workplace, recorded on an electronic audio device and had an average duration of 20 minutes. The focus of the interviews was aspects of the working environment that contribute to and/or hinder nursing practice. The number of participants was defined based on the data saturation criterion.

\section{QuAntitative DATA ANALYSIS}

The analysis of the data occurred through descriptive statistics according to arithmetic mean, median, standard deviation, minimum and maximum values. Data symmetry was verified through sample distribution histograms, although the variables did not present normal distribution. Thus, the non-parametric Mann-Whitney test was used to compare B-NWI-R scores among the nurse managers and nursing assistants. The relationships were considered significant if $\mathrm{p}<0.05$. The analyses were performed using the Statistical Package for the Social Sciences (SPSS) program, version 19.0.

\section{Qualitative DATA ANAlysis}

Data analysis was carried out according to the three stages of the thematic analysis: pre-analysis, material exploration and treatment of results, inference and interpretation ${ }^{(12)}$. The B-NWI-R subscales were used as thematic categories.

\section{ETHICAL ASPECTS}

The present study integrates a macroproject on nursing governance in the hospital environment, which was approved by the Research Ethics Committee under opinion number 144.436/2012, and developed in accordance with Resolution $196 / 96$, in force at the submission time of the project to the
Ethics Committee. The study subjects signed the Free and Informed Consent Form and their speeches were coded by the letter "P" of participant, followed by the number assigned according to the interview order: P1 to P26.

\section{RESULTS}

Participants' socio-professional profile characteristics of the quantitative study are presented in Table 1.

According to the B-NWI-R, the evaluated nursing assistants have control over the environment, organizational support, a good relationship with physicians and autonomy for exercising nursing practice. The nurse managers also considered having organizational support, a good relationship with the physicians and autonomy. However, the subscale control over the environment was evaluated as an unfavorable characteristic, since it had a score above 2.5. No statistical significance was found in the comparison between the working environment of the two groups (Table 2).

Qualitative results are summarized and presented in Chart 1 , according to the B-NWI-R subscales.

The perception that nursing assistants have greater autonomy predominated among the nurse managers, mainly in the nursing care management. Nurse managers consider themselves responsible for the articulation between the unit's demands and the nursing director, which does not necessarily represent autonomy for decision-making. On the other hand, both views on autonomy were obtained among nursing assistants. Some nurses feel they have a hold on what is happening in the sector, playing a central role in the work organization context. However, other nurses affirm that the hierarchical rigidity and hegemony of the biomedical model limits nursing autonomy in the institution.

Table 1 - Socio-professional characterization of the participants - Florianópolis, Santa Catarina, Brazil, 2012-2013.

\begin{tabular}{|c|c|c|c|c|}
\hline \multirow{2}{*}{$\begin{array}{l}\text { Nurses } \\
\text { Variables }\end{array}$} & \multicolumn{2}{|c|}{ Managers $(n=12)$} & \multicolumn{2}{|c|}{ Nursing assistants $(n=94)$} \\
\hline & $\mathbf{n}(\%)$ & $\mathrm{AM}^{*} \pm \mathrm{SD}^{* *}$ & $\mathrm{n}(\%)$ & $\mathrm{AM}^{*} \pm \mathrm{SD}^{* *}$ \\
\hline Age (years) & & $35.92 \pm 7.98$ & & $38.3 \pm 9.66$ \\
\hline \multicolumn{5}{|l|}{ Gender } \\
\hline Female & $12(100)$ & & $86(91.5)$ & \\
\hline Male & - & & $8(8.5)$ & \\
\hline \multicolumn{5}{|l|}{ Marital status } \\
\hline With a partner & $5(41.7)$ & & $48(51.1)$ & \\
\hline Without a partner & $6(50)$ & & $40(42.5)$ & \\
\hline Others & $1(8.3)$ & & $6(6.4)$ & \\
\hline Profissional experience (years) & & $11.55 \pm 8.26$ & & $13.96 \pm 8.72$ \\
\hline Experience at the hospital (years) & & $9.77 \pm 7.8$ & & $12.53 \pm 9.89$ \\
\hline Experience in the sector (years) & & $6.27 \pm 6.26$ & & $7.99 \pm 7.68$ \\
\hline \multicolumn{5}{|l|}{ Training } \\
\hline Specialization & $6(50)$ & & $43(45.7)$ & \\
\hline Master's degree & $5(41.7)$ & & $36(38.3)$ & \\
\hline Undergraduation & $1(8.3)$ & & $9(9.6)$ & \\
\hline Doctorate degree & - & & $6(6.4)$ & \\
\hline Weekly workload (hours) & & $40.91 \pm 13$ & & $36.98 \pm 11.6$ \\
\hline \multicolumn{5}{|l|}{ Other part-time work } \\
\hline No & $9(75)$ & & $80(85.1)$ & \\
\hline Yes & $3(25)$ & & 14(14.9) & \\
\hline
\end{tabular}

${ }^{*} \mathrm{AM}=$ Arithmetic Mean,${ }^{* *} \mathrm{SD}=$ Standard deviation.

Note: $(\mathrm{n}=106)$. 
Table 2 - Comparison of the working environment between nurse managers and nursing assistants - Florianópolis, Santa Catarina, Brazil, 2012-2013.

\begin{tabular}{|c|c|c|c|c|c|}
\hline \multirow{2}{*}{$\begin{array}{l}\text { Nurses } \\
\text { Subscales }\end{array}$} & \multicolumn{2}{|c|}{ Managers $(n=12)$} & \multicolumn{2}{|c|}{ Nursing assistants $(n=94)$} & \multirow{2}{*}{$p$-value } \\
\hline & $\mathbf{A M}^{*}$ & $\mathrm{SD}^{* *}$ & $\mathrm{AM}^{*}$ & $\mathrm{SD}^{* *}$ & \\
\hline Control over the environment & 2.59 & 0.54 & 2.46 & 0.54 & 0.381 \\
\hline Organizational support & 2.21 & 0.42 & 2.20 & 0.41 & 0.971 \\
\hline Physician-nurse relationship & 2.02 & 0.54 & 2.16 & 0.54 & 0.466 \\
\hline Autonomy & 1.93 & 0.95 & 2.09 & 0.51 & 0.365 \\
\hline Total B-NWI-R & 2.15 & 0.39 & 2.22 & 0.39 & 0.508 \\
\hline
\end{tabular}

*AM $=$ Arithmetic Mean, ${ }^{*} \mathrm{SD}=$ Standard deviation.

$\mathrm{p}<0.05 ;$ Mann-Whitney.

Note: $(\mathrm{n}=106)$.

Chart 1 - Aspects of the working environment that contribute to and/or hinder the nursing practice in the hospital environment Florianópolis, Santa Catarina, Brazil, 2012-2013.

\begin{tabular}{|c|c|}
\hline MANAGER & ASSISTANT \\
\hline \multicolumn{2}{|c|}{ Autonomy } \\
\hline $\begin{array}{l}\text { We (nurse managers) have autonomy in part. They (nursing assistant) } \\
\text { can have a greater autonomy, especially in care management (P21). }\end{array}$ & $\begin{array}{l}\text { I know everything that happens in the sector. (...) Everything goes by } \\
\text { me (P17). }\end{array}$ \\
\hline $\begin{array}{l}\text { They are the ones (nursing assistants) who define the patients that go to } \\
\text { another part of the sector, the medication schedule (...), who indicates }\end{array}$ & $\begin{array}{l}\text { It has happened that I had to (...) admit the patient myself (...) and do a } \\
\text { delivery (P15). }\end{array}$ \\
\hline All managers participate at meetings with the Director, and each of & $\begin{array}{l}\text { Unfortunately the institution is still centered on the hegemonic medical } \\
\text { model. So we lose some autonomy (P4). }\end{array}$ \\
\hline & $\begin{array}{l}\text { Things do not always happen as you wish they would because there } \\
\text { are hierarchies to be followed and to obey (P14). }\end{array}$ \\
\hline \multicolumn{2}{|c|}{ Control over the environment } \\
\hline $\begin{array}{l}\text { You cannot be choosing things to do. If you need to do a certain } \\
\text { activity, you end up helping them (nursing assistants) (...) (P20). }\end{array}$ & $\begin{array}{l}\text { Workload is one of the things that hurts me. (...) Stress due to lack of } \\
\text { material, lack of sufficient staff, (...) you can't do anything (P10). }\end{array}$ \\
\hline $\begin{array}{l}\text { The quality of care is not reaching what is desired. (...) We are } \\
\text { understaffed, we don't have the complete team every day and a lot of } \\
\text { things don't get done (P22). }\end{array}$ & $\begin{array}{l}\text { (...) the number of doctor's notes for staff medical leave is increasingly } \\
\text { higher and this ends up hurting the team because it overloads some } \\
\text { individuals, and these things make me feel helpless in this situation } \\
\text { (P13). }\end{array}$ \\
\hline \multicolumn{2}{|c|}{ Relationship with the physicians } \\
\hline $\begin{array}{l}\text { In the care (as an assistant) I had a much better relationship with the } \\
\text { physicians than I do now in a leading role. (...) Before the nurse was } \\
\text { recognized as a leader (...), everything the physician wanted to do they } \\
\text { would question the nurse if they could it and about what was best, and } \\
\text { now the doctors simply come and do whatever they want (P23). }\end{array}$ & $\begin{array}{l}\text { Here, being a school hospital, we have a better opening than in other } \\
\text { hospital settings. We are closer. (P8). } \\
\text { It's a good relationship. (...) We still can't work in a multiprofessional } \\
\text { way, not as we should. But it has improved a lot (P12). }\end{array}$ \\
\hline $\begin{array}{l}\text { Ninety-nine percent of the medical staff relates very well to the nursing } \\
\text { staff, (...) one complements the activity of the other (P19). }\end{array}$ & $\begin{array}{l}\text { It's easy to get along with the doctors. Of course there's always } \\
\text { someone that you pray it isn't their shift. (P13). }\end{array}$ \\
\hline \multicolumn{2}{|c|}{ Organizational support } \\
\hline $\begin{array}{l}\text { We also participate in all the decisions that come from the Nursing } \\
\text { Director (...) (P24). }\end{array}$ & $\begin{array}{l}\text { I can only thank both the immediate supervisor and the nursing } \\
\text { director for how much our relationship is peaceful and open (P6). }\end{array}$ \\
\hline $\begin{array}{l}\text { The nursing board is very close to the managers. We have a forum } \\
\text { every } 15 \text { days where several issues of the sectors are discussed (...), } \\
\text { the nursing director is a nurse who is above us, but they work with us } \\
\text { (P19). }\end{array}$ & $\begin{array}{l}\text { She (the director) is in the same "boat" as we are (...) (P10). } \\
\text { The manager sends all the decisions that are made to us by email (...) } \\
\text { (P13). }\end{array}$ \\
\hline
\end{tabular}

Regarding control over the environment, nurse managers and nursing assistants reported difficulties. The main obstacles highlighted were lack of materials, absenteeism and the high number of sick leaves, which generates work overload and dissatisfaction among the nursing staff. Such limitations also compromise the quality of care provided to patients.

The relationships with physicians were considered good by both groups participating in the study. Nurse managers believe that nursing assistants have better relationships with doctors. Nursing assistants point out that the relationships with physicians have improved over time and are facilitated by the institution's characterization as a hospital school. However, the good relationship between the professional categories does not always culminate in teamwork and interdisciplinary action.

Concerning organizational support, participants emphasized the backing and support of nurses who hold superior 
positions in the institution's organizational structure. Nurse managers emphasized their participation in deliberative meetings with the nursing director and their responsibility for passing on decisions to the team. Nursing assistants highlight the closeness and openness to dialogue with the nurse managers, considering that they share common goals in the organizational context.

\section{DISCUSSION}

Most of the study participants were females aged close to 37 years, which coincides with the sociodemographic profile of Nursing in Brazill ${ }^{(13)}$. We can point out the amount of nurses with lato sensu specialization and with a Masters' degree, which was more expressive than that described in prior national ${ }^{(8,14)}$ and internacional ${ }^{(15-16)}$ studies.

Furthermore, in relation to the socio-professional characterization of the participants, we can point out that the age and performance experience at the institution of the nurse managers were shorter in comparison to nursing assistants. On the other hand, they had a higher level of education with graduation training. This result differs from the reality of health organizations and services, where managerial positions are commonly assumed by nurses with higher professional experience, especially in the clinical area ${ }^{(17)}$. Moreover, professional experience is considered a differential for adequately developing the attributions related to a managerial position in the nursing context ${ }^{(17-18)}$.

In the contemporary context of Administration, professional training has been increasingly valued for the exercise of managerial positions. This contributes to the fact that young professionals with more qualifications than more experienced professionals stand out in exercising managerial positions ${ }^{(19)}$, which could be happening in the investigated scenario. In this sense, it is important that future investigations explore the reasons why nurses have assumed managerial positions and how they have been trained for such activity.

In evaluating the overall scores of the B-NWI-R, both the working environment of nursing assistants and nurse managers were shown to have favorable characteristics. Similar results are described in previous studies using the same instrument in Brazil ${ }^{(8,20)}$.

The four domains of the B-NWI-R were favorable for nursing assistants. However, the control over the environment subscale was unfavorable among nurse managers. This subscale was also negatively evaluated by nurses from critical units of a university hospital in São Paulo ${ }^{(21)}$. Therefore, we point out the need for nurses' control over the environment to be improved in the hospital context.

No statistical significance was identified in comparing the working environments of the two groups. This result suggests the existence of a working environment with similar characteristics for the institution's nurses, regardless of exercising a managerial position. On the other hand, it is important to reflect on the empowerment of nurse managers to identify problems and implement strategies to solve them, which are activities inherent to the position.
Empowerment corresponds to the capacity to intervene in a given context, resulting from formal and informal systems. Formal empowerment results from structures that enable decision-making according to the understanding of what is best for achieving organizational goals, while informal empowerment derives from interpersonal relationships at work ${ }^{(22)}$. The formal empowerment of nurses does not usually increase as they move up the organizational hierarchy ${ }^{(23)}$, and nurse managers often have less power than managers in other hospital areas ${ }^{(24)}$. However, empowered managers can empower others and are more likely to do so than those who do not feel empowered. Moreover, when nurses realize that their managers have influence in the organization, they are more likely to also feel empowered ${ }^{(23)}$, which contributes to higher professional satisfaction and better nursing care results.

In Brazil, the empowerment of nurse managers is influenced by how these professionals reached their position. It is common, especially in public hospitals, for nurses to be elected by their peers to managerial positions or promoted from assistants to managers by the institution, unlike in other countries. In Canada and Australia, for example, nurses outside the health institution are specifically hired for management positions. These nurse managers are directly involved in implementing organizational strategies and they have essential roles for fulfilling present and future ideals of the organizations, as well as to achieve the objectives sought through the established goals for the quality and safety of the care provided by its teams ${ }^{(25)}$.

The results of this study indicate the existence of collaborative relationships between nurse managers and nursing assistants. This finding reinforces the results of a Brazilian study in which teamwork was considered an important competence for nurse managers to promote the integration of their team's professionals in favor of achieving better organizational results ${ }^{(26)}$. A Chinese study identified that nurse managers adopted an autocratic position in relation to nursing assistants, giving them limited power in decision-making processes, creating a working environment that compromises care quality $^{(24)}$.

The hierarchy within the hospital organizational structure permeated by values such as control and rigidity at work, individualism and competition encourages care fragmentation, since it hinders teamwork and the development of interdisciplinary actions, which impair the quality of the provided services. Adopting new forms of work management and organization are health practices that are alternatives to traditional models. Therefore, it is expected that managers and work coordinators will value teamwork and the humanization of interpersonal relationships ${ }^{(27)}$.

In the combination between the quantitative and qualitative results, we observed convergences related to control over the environment, relationships with physicians and organizational support. However, there were differences regarding autonomy. Among the subscales of B-NWI-R, autonomy presented the most positive score. However, the perception that professional autonomy is limited in the institution predominated among the interviewed nurses. 
Nurse managers considered that their autonomy is circumscribed to an articulating role between the demands of the nursing services and the Nursing Director. Thus, the decision-making process is not centered on the nurse manager. A study developed in the South of Brazil also showed that decision-making does not solely arise from the nurse manager of the nursing services. It is passed on to higher levels due to management decentralization, and from there the conducts are adopted through the decision-making process ${ }^{(28)}$.

According to the perception of nursing assistants, autonomy is limited by the hierarchy and influenced by the biomedical model in the hospital. Nurse's autonomy can be considered a relative process, which is constructed from their coexistence with other nursing professionals and the health team. The consolidation of a nurse's autonomy requires the development of technical, scientific, political and humanistic competencies collectively built into the work routine ${ }^{(29)}$.

Control over the environment had the least favorable scores between the two groups of nurses. In the qualitative results, nurses pointed out difficulties regarding lack of materials and personnel. In public institutions, the purchase of materials and hiring of workers depends on the release of financial resources by the government and require execution of public tender solicitations, which is beyond the governability of professionals and managers. In addition, this result may have been influenced by the crisis set in public university hospitals in the country, which negatively interfered with the working conditions of health professionals, especially during the period of data collection. Thus, we can reinforce that the financial constraints of the health system have compromised Nursing productive capacity ${ }^{(5)}$. Also, characteristics of the institution are associated with psychological distress in nursing work, and they can lead to professional exhaustion and overload among professionals ${ }^{(30)}$.

The relationship with physicians was considered positive by the participants, mainly due to the hospital's characterization as a teaching institution. Studies similarly point out that nurses' relationships with physicians in university hospitals are facilitated by the characteristics of these institutions, which seek to promote an environment conducive to autonomy and to developing collaborative work ${ }^{(20,31)}$.

Good relationships do not mean the absence of conflict between these professional categories. Physicians and nurses develop an interdependent practice in the hospital context, which can facilitate triggering of interprofessional conflicts, mainly when differences in points of view and care practices arise ${ }^{(31)}$. Thus, we highlight the difference between the development of multidisciplinary work and the scope of interdisciplinary care. The first concerns an association of different knowledge, while the second goes beyond this interdependence and happens through interaction and dialogue among the different disciplines ${ }^{(32)}$.

Organizational support was evaluated positively by the B-NWI-R and according to the interviews with the two groups participating in the research. Organizational support received by the upper levels of administration is an important stimulus for the managerial practice of nurses ${ }^{(1,20)}$. However, nurses' reports that decisions come from the Nursing Director point to the existence of a decision-making process based on institutional hierarchy, whose results are then informed and/or passed on to the rest of the professionals. Similarly, results from a study in Sweden indicate that nursing assistants have little involvement in decision-making processes, which results in loss of control over their working environments. Nurses who hold managerial positions on the other hand have greater participation in the decision-making process and consequently have a greater sense of control and organizational support ${ }^{(33)}$.

As a limitation of the study, we can point out that the quantitative sample was non-probabilistic and restricted to the group of nurses from one hospital institution. Another limitation refers to the cross-sectional design, in which reverse causality cannot be ruled out.

Regarding advances in the area of nursing/health, this is the first Brazilian study that has compared the working environment of nurse managers and nursing assistants through applying the B-NWI-R and that adopted a mixed research methodology. The results have indicated factors that intervene and negatively impact nurses' work in the hospital environment. Thus, this study provides support for developing strategies to improve nurses' working environments, seeking greater satisfaction for the professional and improvement in the quality of care. In addition, this study also contributes to disseminating research with mixed methods as a methodological strategy among nursing and health researchers.

\section{CONCLUSION}

Integration between the quantitative and qualitative results showed that the working environment is similarly evaluated by nurse managers and nursing assistants in the investigated context. Nursing assistants reported having control over the environment, organizational support, a good relationship with physicians and autonomy. Nurse managers also perceived having organizational support, a good relationship with physicians and autonomy. However, the control over the environment subscale was assessed as being an unfavorable characteristic by nurse managers.

\section{RESUMO}

Objetivo: Comparar o ambiente de trabalho de enfermeiros gerentes e assistenciais no contexto hospitalar. Método: Pesquisa de métodos mistos com triangulação concomitante de dados, desenvolvida em um hospital universitário do Sul do Brasil. Os participantes do estudo quantitativo foram 94 enfermeiros assistenciais e 12 enfermeiros gerentes. Os dados foram coletados a partir do Brazilian Nursing Work Index - Revised (B-NWI-R) e analisados por meio de estatística descritiva e inferencial. Para o estudo qualitativo, foram entrevistados oito enfermeiros gerentes e 18 enfermeiros assistenciais. Os dados foram analisados mediante análise temática. Resultados: A média total do B-NWI-R para os enfermeiros gerentes foi de 2,15 $\pm 0,39$ e para os enfermeiros assistenciais foi de $2,22 \pm 0,39$. Não 
foi identificada significância estatística na comparação entre os grupos ( $p=0,508)$. Os resultados qualitativos mostram a existência de relações colaborativas entre enfermeiros gerentes e enfermeiros assistenciais. Conclusão: $\mathrm{O}$ ambiente de trabalho foi avaliado de modo semelhante pelos enfermeiros gerentes e assistenciais no contexto hospitalar.

\section{DESCRITORES}

Enfermagem; Ambiente de Trabalho; Supervisão de Enfermagem; Pesquisa em Administração de Enfermagem; Hospitais Públicos.

\section{RESUMEN}

Objetivo: Comparar el ambiente laboral de enfermeros gerentes y asistenciales en el marco hospitalario. Método: Investigación de métodos mixtos con triangulación concomitante de datos, desarrollada en un hospital universitario del Sur de Brasil. Los participantes en el estudio cuantitativo fueron 94 enfermeros asistenciales y 12 enfermeros gerentes. Los datos fueron recogidos a partir del Brazilian Nursing Work Index - Revised (B-NWI-R) y analizados mediante la estadística descriptiva e inferencial. Para el estudio cualitativo, fueron entrevistados ocho enfermeros gerentes y 18 enfermeros asistenciales. Los datos fueron valorados según el análisis temático. Resultados: El promedio total del B-NWI-R para los enfermeros gerentes fue de 2,15 $\pm 0,39$ y para los enfermeros asistenciales fue de $2,22 \pm 0,39$. No fue identificada significación estadística en la comparación entre los grupos $(\mathrm{p}=0,508)$. Los resultados cualitativos muestran la existencia de relaciones colaborativas entre enfermeros gerentes y enfermeros asistenciales. Conclusión: El ambiente laboral fue evaluado de modo semejante por los enfermeros gerentes y asistenciales en el marco hospitalario.

\section{DESCRIPTORES}

Enfermería; Ambiente de Trabajo; Supervisión de Enfermería; Investigación en Administración de Enfermería; Hospitales Públicos.

\section{REFERENCES}

1. Lanzoni GMM, Magalhães ALP, Costa VT, Erdmann AL, Andrade SR, Meirelles BHS. Becoming nursing manager in the nested and complex border of caring and management dimensions. Rev Eletr Enf. 2015;17(2):322-32. DOI: http://dx.doi.org/ 10.5216/ree.v17i2.29570

2. Andrade SR, Piccoli T, Ruoff AB, Ribeiro JC, Sousa FM. Normative grounds of health care practice in Brazilian nursing. Rev Bras Enferm. 2016;69(6):1020-8. DOI: http://dx.doi.org/ 10.1590/0034-7167-2016-0228

3. Dall'Agnol CM, Moura GMSS, Magalhães AMM, Falk MLR, Riboldi CO, Oliveira AP. Motivations, contradictions and ambiguities in the leadership of nurses in management positions in a university hospital. Rev Latino Am Enfermagem. 2013;21(5):1172-8. DOI: http://dx.doi. org/ 10.1590/S0104-11692013000500022

4. Numminen O, Ruoppa E, Leino-Kilpi H, Isoaho H, Hupli M, Meretoja R. Practice environment and its association with professional competence and work-related factors: perception of newly graduated nurses. J Nurs Manag. 2016;24(1):E1-11. DOI: http://dx.doi. org/10.1111/jonm. 12280

5. Cucolo DF, Perroca MG. Factors involved in the delivery of nursing care. Acta Paul Enferm. 2015;28(2):120-4. DOI: http://dx.doi.org/ 10.1590/1982- 0194201500021

6. Gasparino RC, Guirardello EB, Aiken LH. Validation of the Brazilian version of the Nursing Work Index-Revised (B-NWI-R). J Clin Nurs. 2011;20:3494-501. DOI: http://dx.doi.org/ 10.1111/j.1365-2702.2011.03776.x.

7. Balsanelli AP, Cunha ICK. The work environment in public and private intensive care units. Acta Paul Enferm. 2013;26(6):561-8. DOI: http://dx.doi.org/ 10.1590/S0103-21002013000600009

8. Panunto MR, Guirardello EB. Professional nursing practice: environment and emotional exhaustion among intensive care nurses. Rev Latino Am Enfermagem. 2013;21(3):765-72. DOI: http://dx.doi.org/ 10.1590/S0104-11692013000300016

9. Oliveira PB, Spiri WC, Dell'Acqua MCQ, Mondini CCSD. Comparison between the accredited and non-accredited public hospital working environments. Acta Paul Enferm. 2016;29(1):53-9. DOI: http://dx.doi.org/ 10.1590/1982-0194201600008

10. Creswell JW. A concise introduction to mixed methods research. Thousand Oaks: Sage; 2014.

11. Gasparino RC, Guirardello EB. Translation and cross-cultural adaptation of the "Nursing Work Index - Revised" into Brazilian Portuguese. Acta Paul Enferm. 2009;22(3):281-7. DOI: http://dx.doi.org/10.1590/S0103-21002009000300007

12. Bardin L. Análise de conteúdo. São Paulo: Edições 70; 2011.

13. Machado MH, Aguiar Filho W, Lacerda WF, Oliveira E, Lemos W, Wermelinger M, et al. Características gerais da enfermagem: o perfil sócio demográfico. Enferm Foco [Internet]. 2016 [citado 2017 mar. 14];7(n.esp):9-14. Disponível em: http://revista.portalcofen.gov.br/ index.php/enfermagem/article/view/686

14. Gasparino RC, Guirardello EB. Ambiente da prática profissional e burnout em enfermeiros. Rev RENE [Internet]. 2015 [citado 2017 mar. 14];16(1):90-6. Disponível em: http://www.periodicos.ufc.br/rene/article/view/2667/2052

15. Desmedt M, De Geest S, Schubert M, Schwendimann R, Ausserhofer D. A multi-method study on the quality of the nurse work environment in acute-care hospitals: positioning Switzerland in the Magnet hospital research. Swiss Med Wkly. 2012;21(142):w13733. DOI: http:// dx.doi.org/10.4414/smw.2012.13733

16. Titzer JL, Shirey MR, Hauck S. A nurse manager succession planning model with associated empirical outcomes. J Nurs Adm. 2014;44(1),3746. DOI: http://dx.doi.org/10.1097/NNA.0000000000000019

17. Van Dyk J, Siedlecki SL, Fitzpatrick JJ. Frontline nurse managers' confidence and self-efficacy. J Nurs Manag. 2016;24(4):533-9. DOI: $10.1111 /$ jonm. 12355

18. Parker V, Giles M, Lantry G, McMillan M. New graduate nurses' experiences in their first year of practice. Nurse Educ Today. 2014;34(1):1506. DOI: 10.1016/j.nedt.2012.07.003

19. Nguyen N, Hansen JØ. Becoming a leader-manager: a matter of training and education. Dev Learn Organ. 2016;30(6):10-12. DOI: 10.1108/DLO-07-2016-0056 
20. Oliveira EM, Barbosa RL, Andolhe R, Eiras FRC, Padilha KG. Nursing practice environment and work satisfaction in critical units. Rev Bras Enferm. 2017;70(1):79-86. DOI: http://dx.doi.org/10.1590/0034-7167-2016-0211

21. Maurício LFS, Okuno MFP, Campanharo CRV, Lopes MCBT, Belasco AGS, Batista REA. Professional nursing practice in critical units: assessment of work environment characteristics. Rev Latino Am Enfermagem. 2017;25:e2854. DOI: http://dx.doi.org/10.1590/15188345.1424 .2854

22. Teixeira AC, Nogueira MAA, Alves PJP. Empoderamento estrutural em enfermagem: tradução, adaptação e validação do Conditions of Work Effectiveness Questionnaire II. Rev Enf Ref. 2016;4(10):39-47. DOI: http://dx.doi.org/10.12707/RIV16014

23. Laschinger HKS, Wong CA, Grau AL, Read EA, Pineau Stam LM. The influence of leadership practices and empowerment on Canadian nurse manager outcomes. J Nurs Mang. 2012;20(7):877-88. DOI: http://dx.doi.org/10.1111/j.1365-2834.2011.01307.x

24. Su SF, Jenkins M, Liu PE. Nurses' perceptions of leadership style in hospitals: a grounded theory study. J Clin Nurs. 2011;21(1-2):272-80. DOI: http://dx.doi.org/10.1111/j.1365-2702.2011.03815.x

25. Brown P, Fraser K, Wong CA, Muise M, Cummings G. Factors influencing intentions to stay and retention of nurse managers: a systematic review. J Nurs Mang. 2012;21(3):459-72. DOI: http://dx.doi.org/10.1111/j.1365-2834.2012.01352.x

26. Furukawa PO, Cunha ISKO. Profile and competencies of nurse managers at accredited hospitals. Rev Latino Am Enfermagem. 2011;19(1):106-14. DOl: http://dx.doi.org/10.1590/S0104-11692011000100015

27. Rocha FLR, Marziale MHP, Carvalho MC, Id SFC, Campos MCT. The organizational culture of a Brazilian public hospital. Rev Esc Enferm USP. 2014;48(2):303-9. DOI: http://dx.doi.org/10.1590/S0080-6234201400002000016

28. Eduardo EA, Peres AM, Almeida ML, Roglio KD, Bernardino E. Analysis of the decision-making process of nurse managers: a collective reflection. Rev Bras Enferm. 2015;68(4):668-75. DOI: http://dx.doi.org/10.1590/0034-7167.2015680414i

29. Dalcól C, Garanhani ML. Management role of surgical center nurses: perceptions by means of images. Rev Eletr Enf. $2016 ; 18:$ e1168. DOI: http://dx.doi.org/10.5216/ree.v18.34888

30. Adriaenssens J, De Gucht V, Maes S. Determinants and prevalence of burnout in emergency nurses: a systematic review of 25 years of research. Int J Nurs Stud. 2015;52(2):649-61. DOI: http://dx.doi.org/10.1016/j.ijnurstu.2014.11.004

31. Oliveira AM, Lemes AM, Ávila BT, Machado CR, Ordones E, Miranda FS, et al. Relação entre enfermeiros e médicos no Hospital das clínicas da Universidade Federal de Goiás: a perspectiva do profissional de enfermagem. Rev Latino Am Bioética. $2010 ; 10(2): 58-67$.

32. Velloso MP, Guimarães Maria BL, Cruz CRR, Neves TCC. Interdisciplinarity and training in the collective health area. Trab Educ Saúde. 2016;14(1):257-71. DOI: http://dx.doi.org/10.1590/1981-7746-sip00097

33. Johansson G, Sandahl C, Hasson D. Role stress among first-line nurse managers and registered nurses: a comparative study. J Nurs Manag. 2011;21(3):449-458. DOI: http://dx.doi.org/doi: 10.1111/j.1365-2834.2011.01311.x 